\title{
The Application of GIS and Remote Sensing in a Spatiotemporal Analysis of Coastline Retreat in Rufisque, Senegal ${ }^{3}$
}

\begin{abstract}
This paper is aimed at analyzing the phenomenon of shoreline retreat in the locality of Rufisque from 1978 to 2018 mainly using geospatial data and field visits. A set of Landsat images from different dates at 10 year intervals was then acquired through the United States Geological Survey platform and shoreline change analysis was run using the Digital Shoreline Analysis System. In addition to that desktop work, interactions with local residents allowed the determination of ongoing adaptation strategies actually in place to cope with coastal erosion. The study showed that Rufisque is subject to serious rates of erosion reaching $-19.48 \mathrm{~m} /$ year from 1978-1988, close to $-8 \mathrm{~m} /$ year from 1988-1998, $-5.88 \mathrm{~m} /$ year from 1998-2008 and $-6.67 \mathrm{~m} /$ year from 2008-2018. Beside that coastal erosion, it has been noticed that the coastline also experienced in some of its parts cases of accretion reaching $4.94 \mathrm{~m} /$ year for 1988-1998, $7.29 \mathrm{~m} /$ year from 1998-2008 and 7.68 m/year during the period 2008-2018. In terms of surfaces, Rufisque' shoreline respectively lost 156.81 ha (1978-1988), 80.55 ha (1988-1998), 6.94 ha (1998-2008), 12.93 ha (2008-2018) and in the same note gained 2.86 ha (1988-1998), 32.51 ha (1998-2008) and 19.16 ha (2008-2018) attesting to the fact that the coastline is subject to both spatiotemporal changes. Finally, this study also reveals that while authorities' reaction is taking place at much lower pace, local communities are actually using their ingenuity to put in place strategies to tackle coastal erosion.
\end{abstract}

Keywords: spatiotemporal change, coastline, erosion, accretion, adaptation, Rufisque

Received: 16 February 2021; accepted: 8 March 2021

(C) 2021 Authors. This is an open access publication, which can be used, distributed and reproduced in any medium according to the Creative Commons CC-BY 4.0 License.

1 University of Ibadan, Pan African University Institute of Life and Earth Sciences, Department of Environmental Management, Ibadan, Nigeria, email: tidianecheikh90@yahoo.fr,

ORCID ID: https://orcid.org/0000-0003-2979-1179

2 University of Ibadan, Faculty of Social Sciences, Department of Geography, Ibadan, Nigeria, email: ayoadejo@yahoo.com

3 This research has been funded by the Pan African University through the African Union Commission. 


\section{Introduction}

Sea level rise is one of the major consequences of global warming. It is mainly due to the thermal expansion of oceans, the melting of mountain glaciers as well as margins of Greenland' ice caps and Antarctica [1]. "However, as the rate of sea-level rise accelerates, it may increasingly become the driving force in coastal changes" [2]. Accelerated rates of sea level could cause the flooding of low-lying land, saltwater intrusion into groundwater and streams, increased extent and severity of storm flooding, and coastal erosion.

With over $700 \mathrm{~km}$ of coastline, Senegal is located at the western point of the African continent. In addition to the huge biodiversity characterizing this coastline, it provides important goods and services to the local economy. These $700 \mathrm{~km}$ of coastal zones are widely open to the Atlantic Ocean and can be described as follows; $300 \mathrm{~km}$ of sandy coast; $234 \mathrm{~km}$ of mangroves and estuary zones and $174 \mathrm{~km}$ of rocky coast. This situation makes it susceptible to phenomena such as inundation and coastal erosion. "Observed shoreline erosion rates vary with location, but are on average between one and two meters per year for sandy beaches, and $0.1 \mathrm{~m}$ to $0.7 \mathrm{~m}$ for rocky coasts in Senegal" [3: pp. 7-8]. In addition to this, "More than 50 percent of the coastline is at high risk while 25 percent of Senegal's coast is at high risk of coastal erosion from rising sea levels" [4]. In less than (50) years, an average decline of 1 to $1.30 \mathrm{~m} /$ year has been observed causing loss of settlements and infrastructures particularly in the "Cape Verde peninsula", the "Grande Côte" and "Petite Côte".

The locality of Rufisque is particularly sensitive to coastal erosion. Between 1933 and 1988, coastline retreat was estimated at $1.30 \mathrm{~m}$ [5: pp. 53-82]. However, the protective walls have intensified the recession rates of Rufisque shoreline especially at the extremities of these structures, causing rapid erosion at the seafront of the local graveyard and threatening houses and other economic infrastructures. According to Niang et al. [6], a $1 \mathrm{~m}$ sea level rise would result in the disappearance of $46-63 \%$ of beaches by coastal erosion and $3.5-25 \%$ of the area by inundation. In some areas like Bargny, fishing communities are experiencing serious losses of amenities due to frequent storm surges. About 300 buildings housing almost 2250 dwellers are estimated to be impacted by 2080 [3]. According to Drammeh [7: pp. 43-46], recent studies conducted by International Union for Conservation of Nature through a comparison between the positions of the high water mark limit on aerial photographs and satellite images between 1954 and 2006, shows a significant regression of Rufisque' beach from 0.4 to $1.5 \mathrm{~m} /$ year.

Studies on coastal erosion have indeed gained particular attention from researchers using different approaches. Through a simple comparison of the position of shorelines from different dates, the European Commission [8] concluded that erosion affects $40 \%$ of the beaches of the European Union and more than $50 \%$ of sandy coasts in France. In the United States, the comparison of historical shorelines of (1800s, 1930s, 1970s) with the operational mean high-water shoreline has 
proved that at least $66 \%$ of the sandy coastal strip of the Gulf of Mexico is set back [9] and $45 \%$ of beaches from Florida to North Carolina [10] as well as $40 \%$ of Californian beaches [11: pp. 13-14]. Based on a long-term morphodynamic and stratigraphy analysis of coastal barriers, annual shoreline mapping using the Differential Global Positioning System (DGPS) and local beach profile measurements, Dillenburg et al. [12], respectively estimated that $81-84 \%$ of the beaches of the State of Rio Grande do Sul (Brazil) would be eroded. In Asia, Gopinath and Seralathan [13] showed by comparing Landsat imageries of 1996, 1998, 1999 to a topographic map of 1967 that in the Bay of Bengal, erosion has affected $29.8 \mathrm{~km}^{2}$ of the Sagar Island between 1967 and 1999. El-Hattab [14], assessed the vulnerability of the Northern Mediterranean coast of the Nile Delta using Landsat imageries and an improved Coastal Vulnerability Index incorporation 10 variables (geology, geomorphology, topography, slope, erosion/accretion, mean sea level rise, and coastal protection, population density and socioeconomic status...) and revealed that over $29.64 \%$ of the considered coastline is at a very high risk. Recently, Torresan et al. [15] assessed the vulnerability of the Mediterranean coasts of Egypt using a climate improved coastal vulnerability index that proposed a new approach incorporating geological and socioeconomic parameters in addition to physical ones. This showed that approximately $43 \mathrm{~km}^{2}(1 \%)$ of the coastal area is at high and very high risk while over $80 \%\left(4652 \mathrm{~km}^{2}\right)$ has been classified at low vulnerability. In East Africa, an assessment of the evolution of the Kudichi coastline (Dar es Salam/Tanzania) through superposition and analysis of aerial photographs of 1981, 1992 and 2002 showed that between 1981 and 2002, 0.61 ha of land was eroded in the Kudichi area, with an important accretion of about $2.21 \mathrm{ha}$, a loss 0.40 ha of mangrove area has been also recorded [16]. In West Africa, Ozer et al. [17] used high resolution Google Earth images to evaluate trends of coastline changes in Benin and Togo from 2000 to 2015 and revealed that $52 \%$ of the coastline is undergoing erosion processes while some sections experience an accumulation (14\%).

In Senegal, coastline retreat analysis involved 2 major approaches over time. The first one was mostly oriented towards the interpretation of ancient geological map with reference to the sea level (marine transgression and regression). The second approach dealt with the analysis of contemporary geospatial tools involving aerial photographs, cadastral maps and recently satellite images. In the particular area of Rufisque, coastline change studies were essentially based on the analysis of iconographic documents (aerial photographs, topographic maps, cadastral maps, nautical charts, high resolution satellite images). Diallo [18], detected a shoreline evolution rate of $-1.29 \mathrm{~m}$ /year in Rufisque using topographic maps (1933, 1948), cadastral map (1987), and non-rectified aerial photographs (1980). In the same area, a coastline erosion of $1.3 \mathrm{~m} /$ year has been recorded by Sall [19] by analyzing cadastral maps $(1933,1945)$ and a non-rectified aerial photograph of 1980 while Niang-Diop [20] used non-rectified aerial photographs of (1959, $1968,1972,1976,1980)$ to come up with $-1.2 \mathrm{~m}$ of annual coastal change. Dieye [21] 
showed that the coastline from Bel Air to Rufisque was subject to annual erosion of $0.6 \mathrm{~m} /$ year by using rectified aerial photographs of 1968-1997. The same process was used by Guerin [22] to detect a coastline retreat of 0.77 per year. However, nowadays, the availability of satellites imageries as well as the various automatic methods of geospatial analysis has positively contributed to the monitoring of coastal disasters such as coastal erosion. This study thus proposes a newer approach of coastline change assessment using Satellite imageries and the Digital Shoreline Analysis System (DSAS). It analyzes the spatiotemporal dynamics of coastline retreat in the locality of Rufisque from 1978 to 2018 at ten year intervals, while determining the adaptation measures of local communities.

\section{Materials and Methods}

\subsection{Study Area}

Originally, Rufisque was a Lebou fishing village called Tenguedj (Wolof: Tëngéej) and became important in the 16th century as the principal port of the kingdom of Cayor, being frequented by colonial masters. Its population was estimated at 179,797 in 2002 and 490,694 in 2013 and the ethnic groups of Wolofs, principally Lebous fishermen, are mostly represented [23: pp. 20-22].

Rufisque belongs to the geological area of the Cape Verde peninsula. It is located $25 \mathrm{~km}$ from Dakar and spans about $42 \mathrm{~km}^{2}$. According to Dubresson [24], the area of Rufisque results from tectonics (Paleocene horts of Ndiass and Dakar, exposure of the Lutetian marl-limestone substratum in the Miocene) as well as volcanic eruptions accompanying recent breaks. Its attachment to the main body of the Senegalese basin probably emanates from sea level' pulsations and climatic oscillations of the Quaternary. The evolution of the basin was indeed subject to different phases of marine transgressions and regressions responsible of a diversity of sedimentary formations: from the Cretaceous to the Paleocene, essentially sandstone-clay marine formations. From Paleocene to Eocene a general regression giving a biochemical sedimentation (clayey-marly) which gradually becomes continental, containing inherited lateritic alterations [25]. Its geographical position, oceanic frame and influence of North-North-East marine trade winds is favoring the maintenance of Guinean affinities flora with specific environment including cool temperatures from January to February [25].

Figure 1 shows a global presentation of the department of Rufisque with its main coastal localities and boundaries.

Fishing still remains one of the major activities and the town also offers opportunities of tourism because it conserves significant core of buildings in the French colonial style. Figure 2 illustrates the conserved colonial constructions of the main city of Rufisque with their characteristic wrought-iron balconies and arcades, pitched roofs of imported clay tiles. 


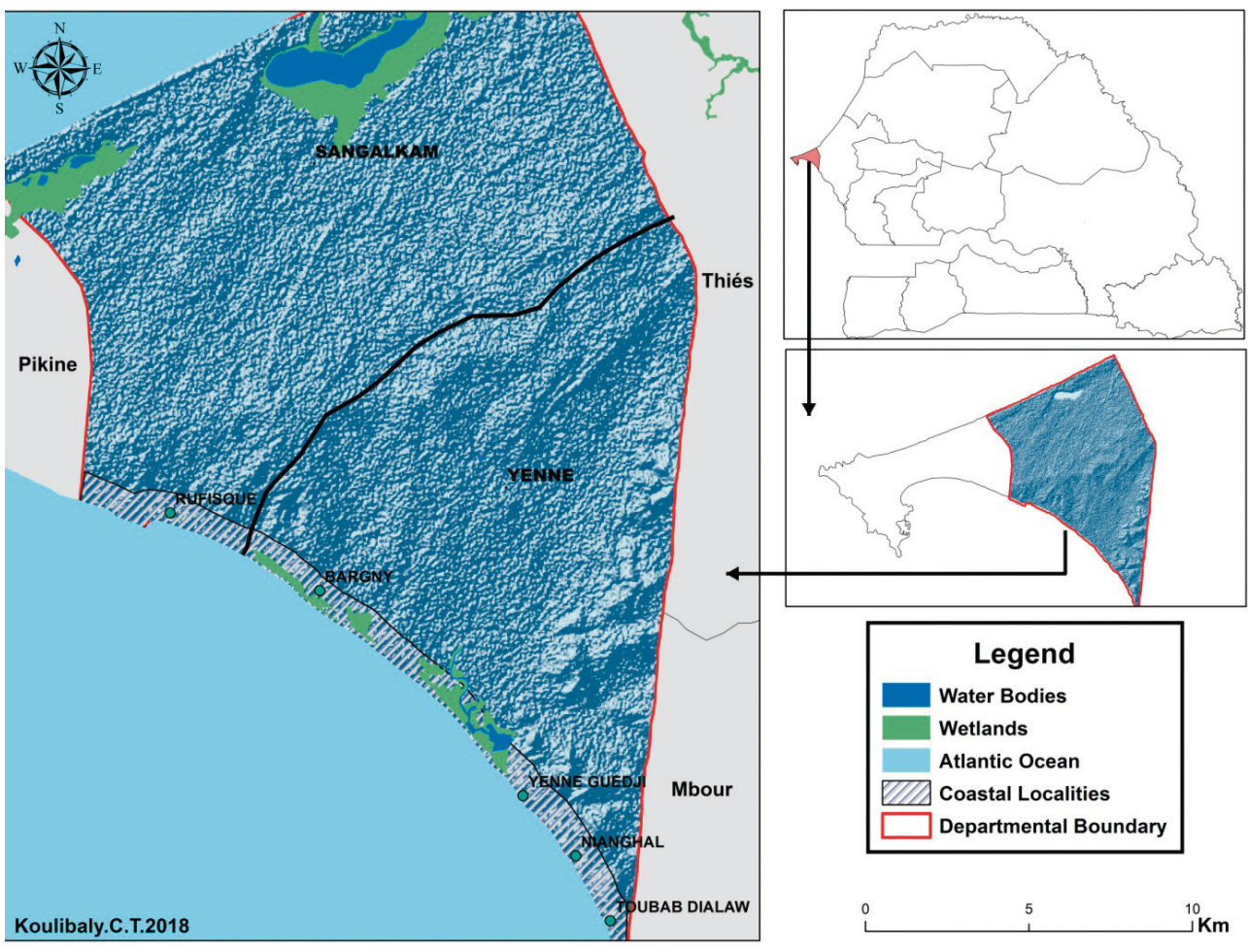

Fig. 1. Location of Rufisque

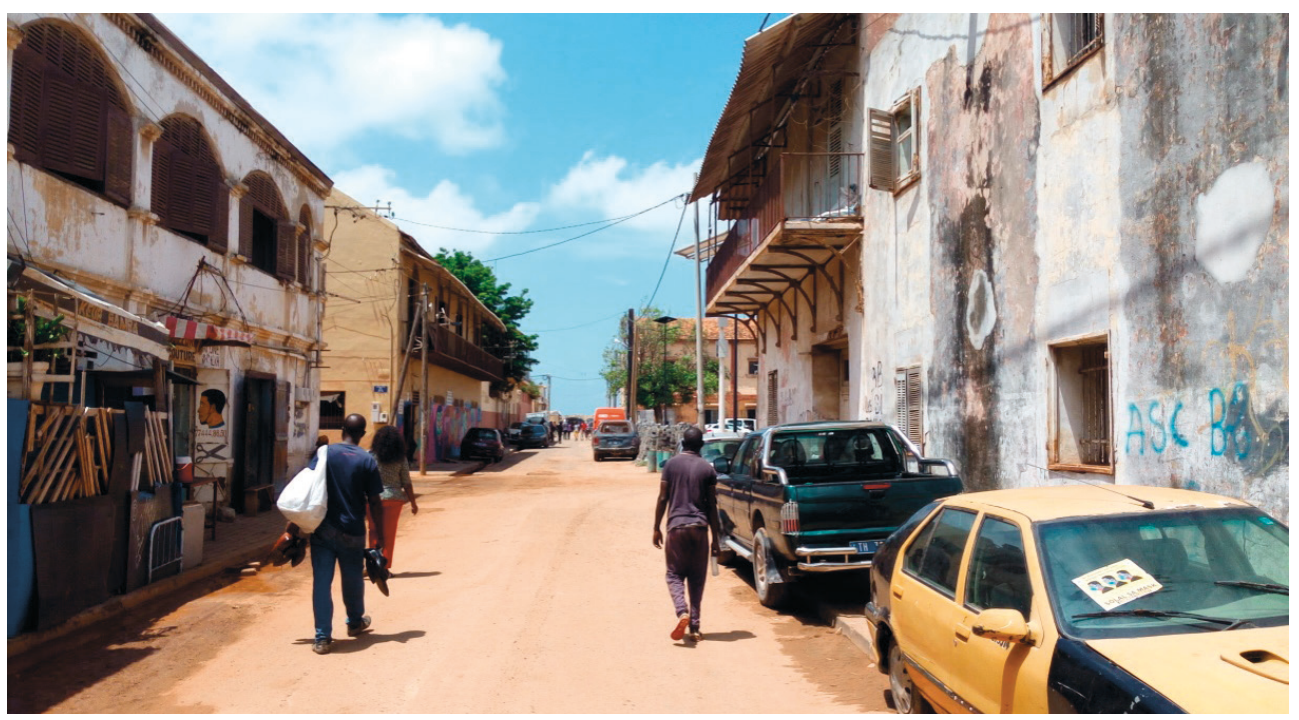

Fig. 2. View of Rufisque with colonial architectural buildings (author's field visit - August 2020) 


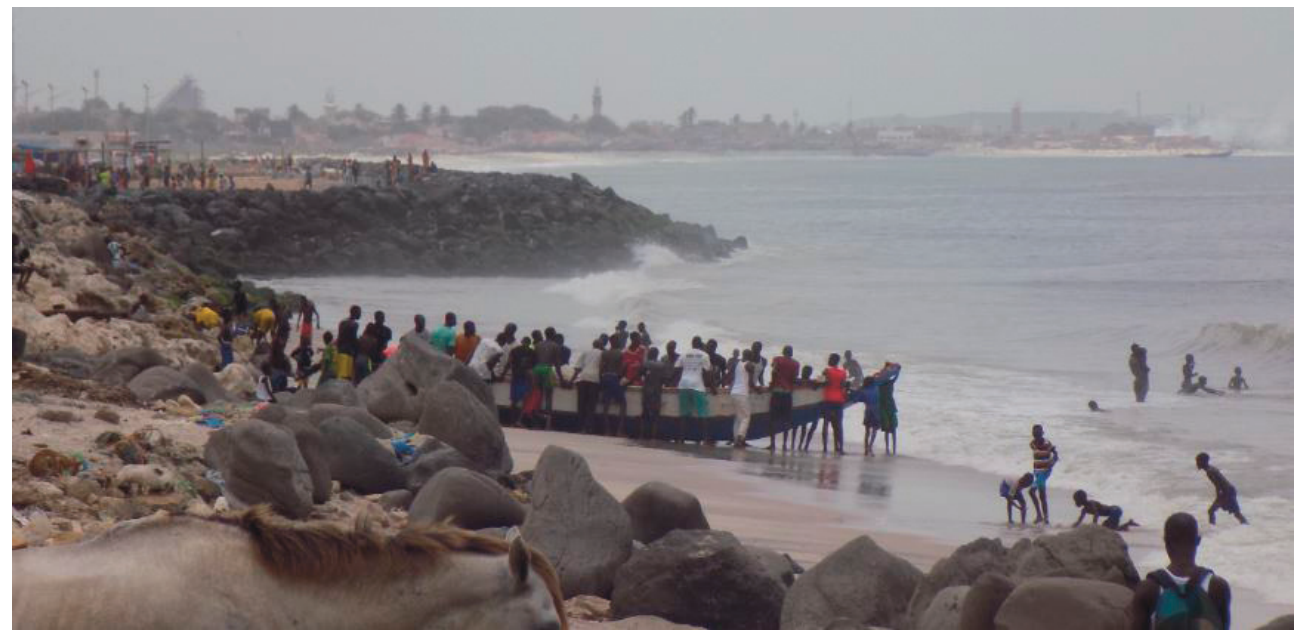

Fig. 3. Typical fishermen coastal community of Rufisque (author's field visit - August 2020)

Figure 3 shows the typical environment of coastal communities characterized by the importance given to the fishing activity and the concentration of people along the shore.

\subsection{Activities}

\section{Data Acquisition}

Shoreline movement studies often results in field measurements of the "coastline" based on the evolution of certain environmental indicators more or less linked to altimetry, hydrodynamics, geomorphology or botany. However, these local measurements are heterogeneous due to the diversity of survey methods and tools, the multiplicity of operators as well as the variety of surveying periods.

Various activities were carried out in this study and the first set of information was acquired from the field through direct observation, GPS mapping, pictures and interviews. The second activity included the acquisition of satellite Landsat imageries from different dates: 1978, 1988, 1998, 2008, and 2018 by MSS (Multispectral Sensor: Landsat 1, 2, 3), TM (Thematic Mapper: Landsat 4 and 5), ETM+ (Ehanced Thematic Mapper: Landsat 7) and OLI and TIRS (Operation Land Imager/Thermal Infrared Radiation: Landsat 8) from the United State Geological Survey (USGS) platform (Tab. 1).

Nowadays, the development of free tools, providing proven algorithms for extracting information from images, facilitating access to data with the establishment of data sharing platforms, make increasingly affordable satellite imagery in terms of cost and technicality [26]. "Landsat imagery can be an alternative source of data for shoreline mapping, while shoreline extraction methods can be conducted using water index, which is easy to perform" [27]. 
Table 1. Details of Landsat images used in the study

\begin{tabular}{|c|c|c|c|c|c|c||}
\hline $\begin{array}{c}\text { Date of } \\
\text { acquisition }\end{array}$ & Sensor & $\begin{array}{c}\text { Resolution } \\
{[\mathrm{m}]}\end{array}$ & Path/Row & $\begin{array}{c}\text { Cell } \\
\text { size }[\mathrm{m}]\end{array}$ & $\begin{array}{c}\text { Coordinate } \\
\text { system/Datum }\end{array}$ & Zone \\
\hline \hline 1978-01-17 & LANDSAT_3/MSS & 60 & $221 / 50$ & $60 / 60$ & UTM/WGS84 & 28 \\
\hline $1988-11-29$ & LANDSAT_5/TM & 30 & $205 / 50$ & $30 / 30$ & UTM/WGS84 & 28 \\
\hline $1998-03-14$ & LANDSAT_5/TM & 30 & $205 / 50$ & $30 / 30$ & UTM/WGS84 & 28 \\
\hline $2008-03-17$ & LANDSAT_7/ETM+ & 30 & $205 / 50$ & $30 / 30$ & UTM/WGS84 & 28 \\
\hline 2018-12-27 & LANDSAT_8/OLI & 30 & $205 / 50$ & $30 / 30$ & UTM/WGS84 & 28 \\
\hline
\end{tabular}

Source: earthexplorer.usgs.gov

The Landsat imageries used in this study were selected according to seasons to avoid as much errors emanating from tidal fluctuations. They were collected during the dry season (November - May) where the tidal ranges are less important with limited occurrence of surges compare to the raining season (June - October). It is also important to emphasize that images of February were avoided because of strong tidal movements accompanied with storm surges mainly due to the predominance of trade winds occurring during that month.

\section{Shoreline Delineation}

For older periods, shorelines were only able to be extracted from aerial photographs. But recently, many techniques are used to map shorelines: use of differential GPS, geodimeter, Lidar data... These tools are used to locate a marker from the shoreline, which can be an altitude, a break in slope in the profile of a beach, the foot a dune, or a cliff or any other suitable landmark [28]. In many cases, the upper high water level line is mostly used in shoreline detection; it generally corresponds to the limit of stable vegetation or the edge of an erosion process. According to Grenier and Dubois [29], this limit is rather constant and stable and constitutes the best limit to use for coasts without cliffs (beach terrace, littoral spit) with a view to coastal development. In the case of artificial coasts, the upper limit of the protective structures is used.

In this study, shorelines were extracted from Landsat images by land-sea interface detection techniques using unsupervised classification algorithms or supervised classification algorithms through ArcGIS 10.1. Remote Sensing was then used to classify the different images into 2 classes in order to create a binary image that clearly separated the water bodies (ocean) from its land surrounding (Fig. 4), raster files are finally converted into vector format and shorelines are then extracted through digitization process. 

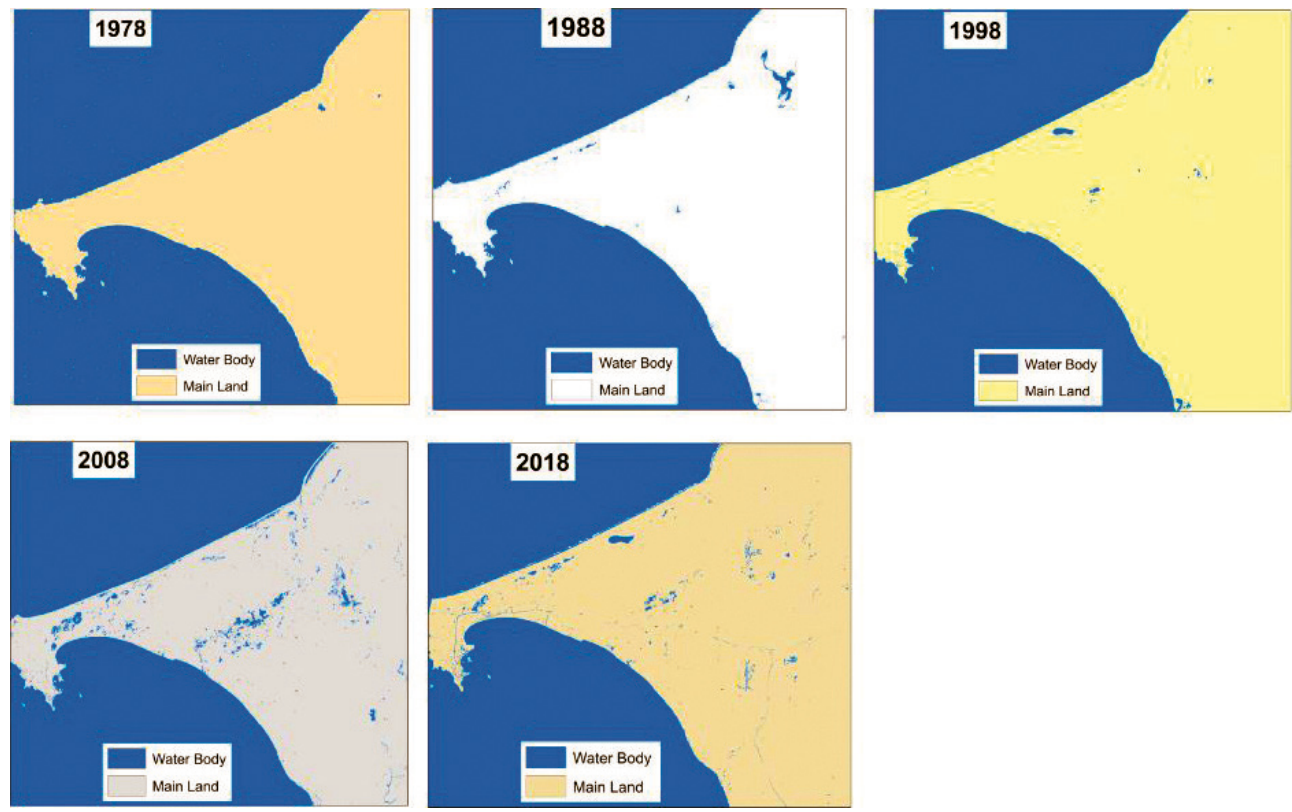

Fig. 4. Binary classification used for shoreline extraction in Rufisque

\section{Shoreline Change Analysis}

Over time, shoreline change rate studies are carried out by means of the comparison of georeferenced plots with several dates. In this case, obtained shorelines from different dates were grouped in one feature class of ArcGIS 10.1 software and then projected at the appropriate ZONE $28 \mathrm{~N}$ for the final Analysis using the Digital Shoreline Analysis System that is indeed able to provide an accurate calculation of the coastline change rates. DSAS is an extension of ArcGIS software performing statistical measurements related to the distance of the position of the shoreline between different dates. Nowadays, it is widely trusted and used in coastline monitoring studies. Mishra et al. [30] found that from 1994 to 2020, a total of 99 documents in the Web of Sciences database (WoS) used DSAS as method of coastline change monitoring. Yet in 2008, Dewidar and Frihy [31] applied it to calculate shoreline changes of pre and post beach response to protection infrastructures erected in the Nile Delta. DSAS was also involved in the study of coastline evolution in Guyana from 1950 to 2013 showing a great variability of the coastline in time and space with amplitudes of variation among the largest in the world varying between 100 and $200 \mathrm{~m} /$ year [32]. It has also been used in mapping coastline's dynamics in Ivory Coast from 1998 to 2004 and provided as results an average erosion rate ranging from 0.84 to $2.09 \mathrm{~m} /$ year [33]. In Turkey, the processes of erosion and accretion from 1939 to 2009 along Iztuzu coastal area were investigated through DSAS and determined coastline changes from -0.3 to $+0.3 \mathrm{~m} /$ year over 77 years [34]. Recently 
in 2020, Thinh et al. [35] applied the Digital Shoreline Analysis system in an analysis of mangrove shoreline changes along the Giao Thuy coastal area (Vietnam) from 2005 to 2014 revealing an average degradation rate of $1.41 \mathrm{~m} /$ year and the growth rate of $1.26 \mathrm{~m} /$ year.

DSAS calculations are done through transects built along the shorelines. A baseline is then constructed to serve as the starting point of all transects. The intersections between each transect and shorelines represent the point of measurement used to calculate the shoreline evolution rate. In our study, transect spacing was $5 \mathrm{~m}$ while the length was related to the distance between shorelines. Since we are more interested in rating the evolution of the coastlines at 10-year intervals, the End Point Rate (EPR) was used as method of calculation. The End Point Rate is the calculation provided by dividing the distance of the oldest and most recent shoreline by the time elapsed between them. The End Point Rate is only used to calculate the rate of erosion/accretion between two shorelines (the oldest and youngest) expressed in $\mathrm{m} /$ year and given by the equation below:

$$
E P R=\frac{\text { Distance between shorelines }[\mathrm{m}]}{\text { Time }}
$$

Finally, the annual error $(E)$ was calculated using the uncertainties assigned to the set of images and the elapsed time in years between images through DSAS (Tab. 2). In this study, the annual shoreline change rate error $(E)$ was computed using Hapke et al. [11] formula given by:

$$
E=\frac{\sqrt{d_{1}^{2}+d_{2}^{2}}}{T}
$$

where $d_{1}$ and $d_{2}$ represent the estimated uncertainties of the different Landsat images and $T$ is the time (in years) elapsed between images.

Table 2. Annual errors associated to shoreline change rate

\begin{tabular}{||c|c||}
\hline Period & Annual error [m/year] \\
\hline \hline $1978-1988$ & \pm 7.11 \\
\hline $1988-1998$ & \pm 4.29 \\
\hline $1998-2008$ & \pm 4.28 \\
\hline $2008-2018$ & \pm 4.32 \\
\hline
\end{tabular}

In order to complete this metric analysis of the shoreline evolution rate, we also deemed it necessary to run a superficies analysis of eroded and accreted areas using remote sensing, digitizing and geometric calculation process. Unsupervised 
classification algorithms or supervised classification algorithms functions were used to create a binary image that separate water bodies to land surrounding. This calculation was also done using our 10 years interval analysis: 1978 to 1988,1988 to 1998 , 1998 to 2008 , and 2008 to 2018. The 2 binary images of each of these 2 dates were then overlaid one on top the other, from the most recent to the oldest for erosion detection and from the oldest to the youngest for accretion detection.

\section{Results}

The results emanating from the analysis of shoreline changes show that the coastline has been unstable over the considered period (1978-2008). Both erosion and accretion phenomenon were noticed along the coastline but were strongly variable according to time and space.

\subsection{Shoreline Change Rate}

\section{Shoreline Change Rate from 1978 to 1988 (Figs. 5, 6)}

Between 1978 and 1988, the analysis illustrated by Figure 5 reveals the shoreline is strongly affected with a retreat ranging from -1 to -19.48 from Rufisque to Toubab Dialaw.

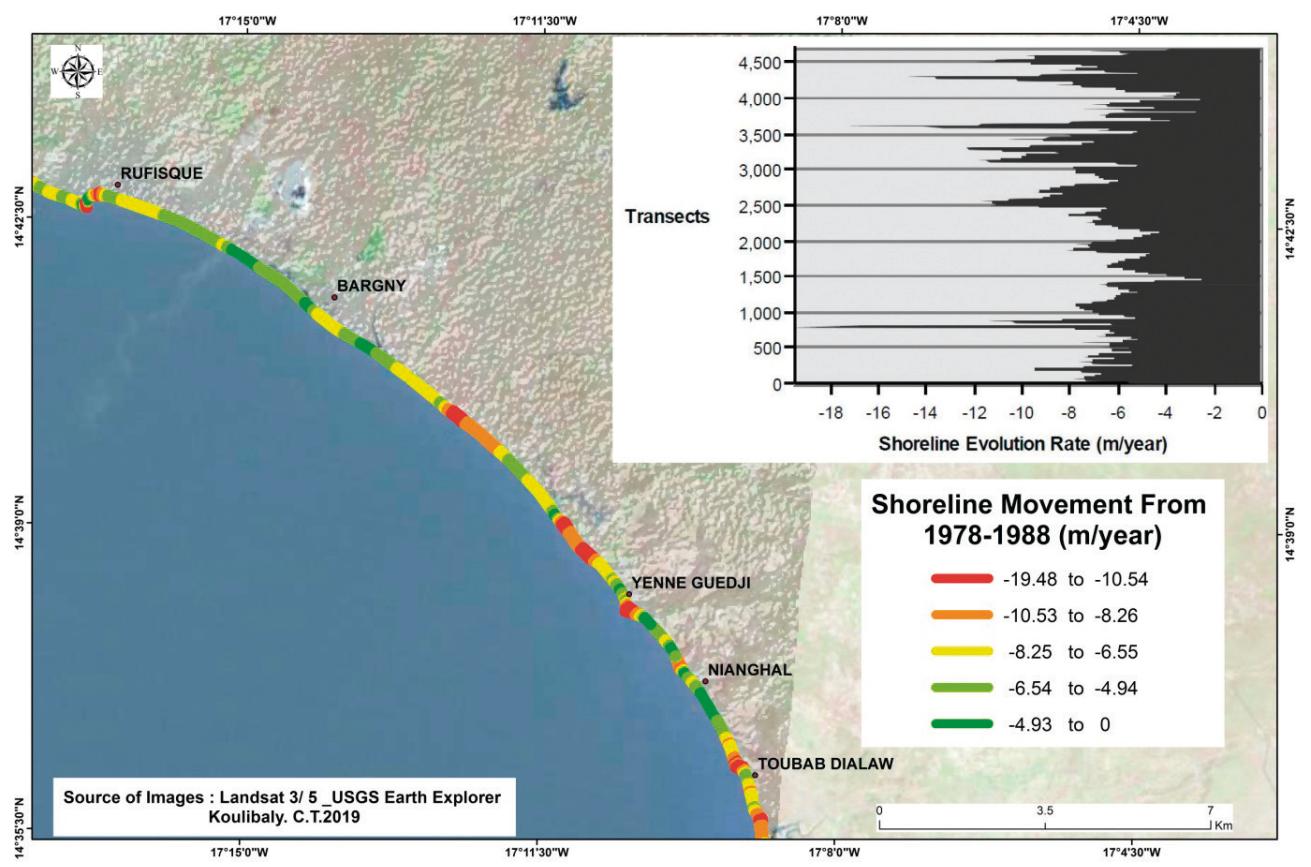

Fig. 5. Shoreline change rate from 1978 to 1988 
Over this period, the coastline was mainly marked by the process of erosion with a maximum of $19.48 \mathrm{~m} /$ year, minimum of $-1 \mathrm{~m} /$ year and a mean rate estimated at $-6.95 \mathrm{~m} /$ year. This coastline retreat varies according to the different localities, in main Rufisque, a rate of $-6.25 \mathrm{~m} /$ year retreat was recorded and -6.94 to $-8.25 \mathrm{~m} /$ year toward the south. Around Bargny, the coastal erosion rate was estimated at $-7.99 \mathrm{~m} /$ year while in the village of Yenne Guedj the retreat was ranging from -5.37 to $-8.22 \mathrm{~m} /$ year. A rate of $-6.2 \mathrm{~m} /$ year has been noticed at Nianghal and about -13.84 to $-5.64 \mathrm{~m}$ towards Toubab Dialaw. It is also important to emphasize that from 1978-1988 no accretion rate has been recorded throughout the coastline of Rufisque.

Another analysis mainly based on the calculation of eroded and accreted areas in hectares also showed that from the period of time (1978-1988) the surfaces in erosion are far greater than those in accretion, as shown in Figure 6.

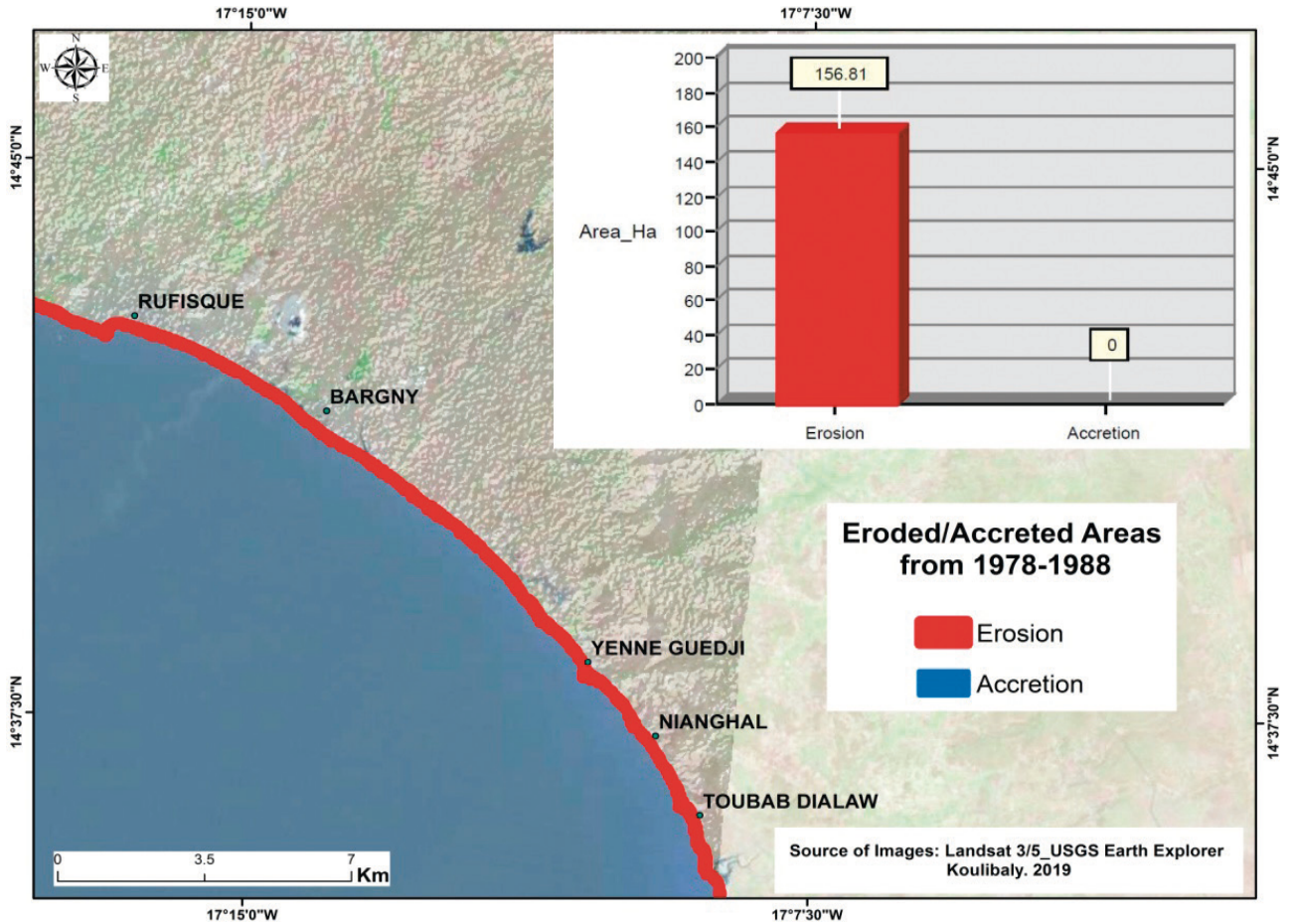

Fig. 6. Eroded/accreted areas [ha] from 1978 to 1988

Figure 6 shows that from 1978 to 1988 the total eroded surfaces were estimated at 156.81 ha while no accretion has been recorded across the coastline of Rufisque, attesting to the huge sedimentary deficit.

\section{Shoreline Change Rate from 1988 to 1998 (Figs. 7, 8)}

Within this period 1988-1998, Figure 7 shows that both erosion and accretion have been noticed across the coastline. 


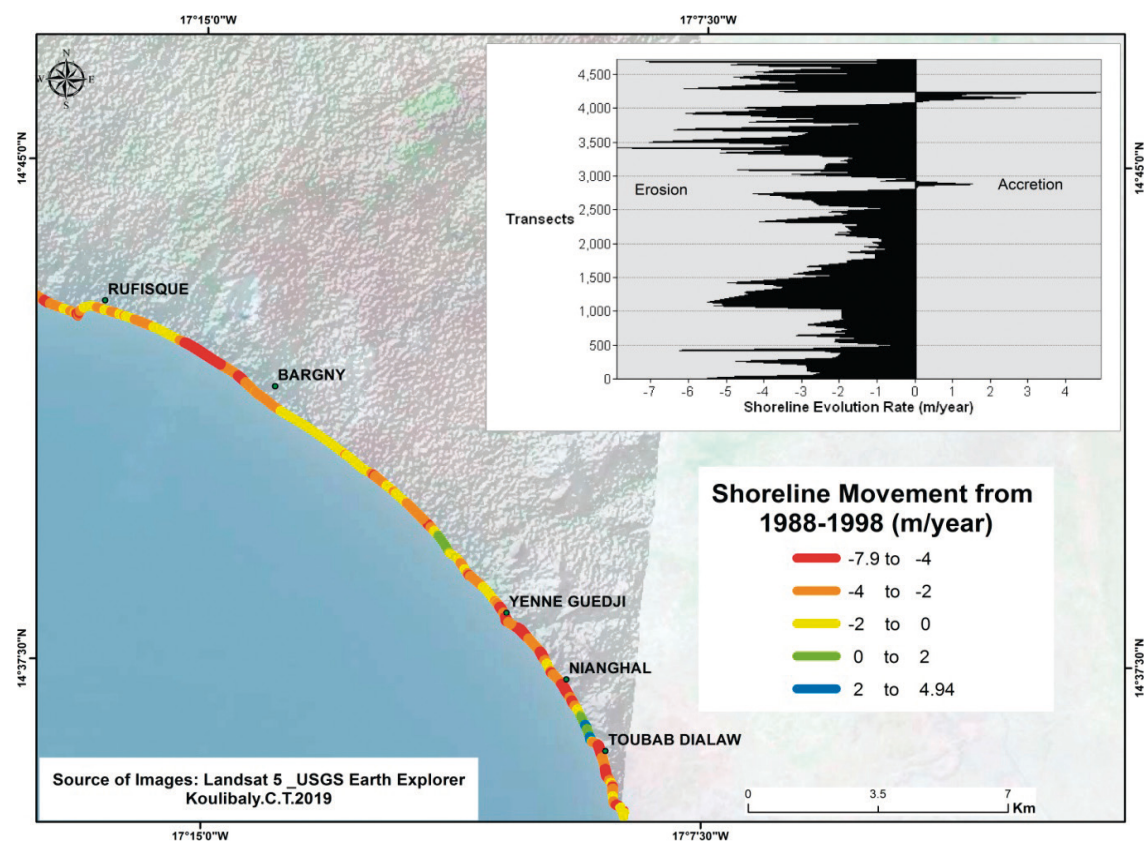

Fig. 7. Shoreline change rate from 1988 to 1998

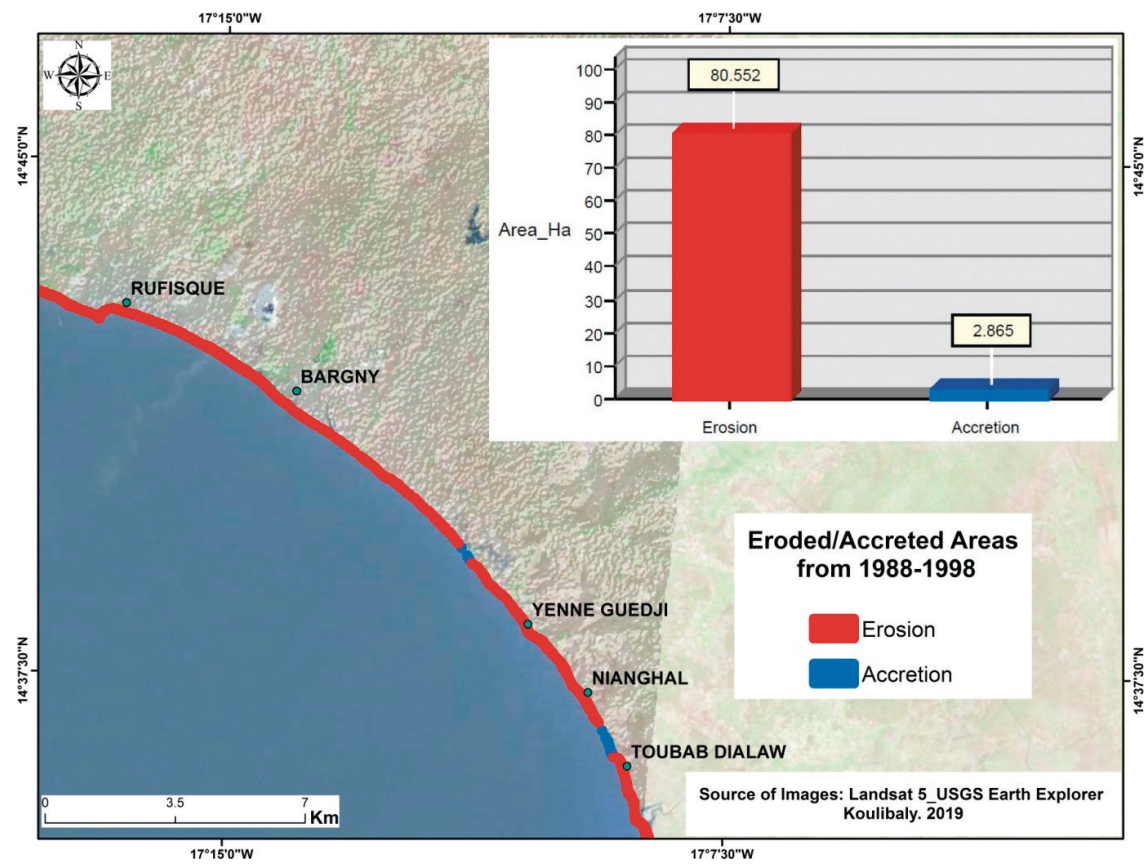

Fig. 8. Eroded/accreted areas [ha] from 1988 to 1998 
Erosion processes ranging from -0.1 to $-7.9 \mathrm{~m} /$ year have been recorded from the coastal sections of Rufisque to Nianghal while accretion phenomenon of 0.11 to $4.94 \mathrm{~m}$ /year only occurred towards the locality of Toubab Dialaw which is still eroded in some of its parts. The mean rate of coastline change was estimated at $-2.58 \mathrm{~m} /$ year, showing net regression compared to the 1978-1988 period.

However, the surface analysis illustrated by Figure 8 shows that the phenomenon of erosion remained more important than accretion with a clear sedimentary deficit.

From 1988 to 1998 the estimated eroded surface was about 80.552 ha on 2.865 ha of accreted areas showing an important sedimentary deficit of 77.687 ha and a rate of $8.05 \mathrm{ha} /$ year of erosion and $0.28 \mathrm{ha} /$ year of accretion. Even if the surface of eroded areas has tremendously decreased compared to 1978-1988, erosion still remained a serious problem in that time.

\section{Shoreline Change Rate from 1998 to 2008 (Figs. 9, 10)}

From 1998 to 2008, the mean rate of coastline change provided by the analysis was estimated at $1.04 \mathrm{~m} /$ year. This indicates that this period was marked by important accretion as shown in Figures 9 and 10.

Figure 9 shows that during this period, the coastline was obviously marked by important accretion ranging from 0.1 to $7.29 \mathrm{~m} /$ year and less important erosion from -0.1 to $-5.88 \mathrm{~m} /$ year.

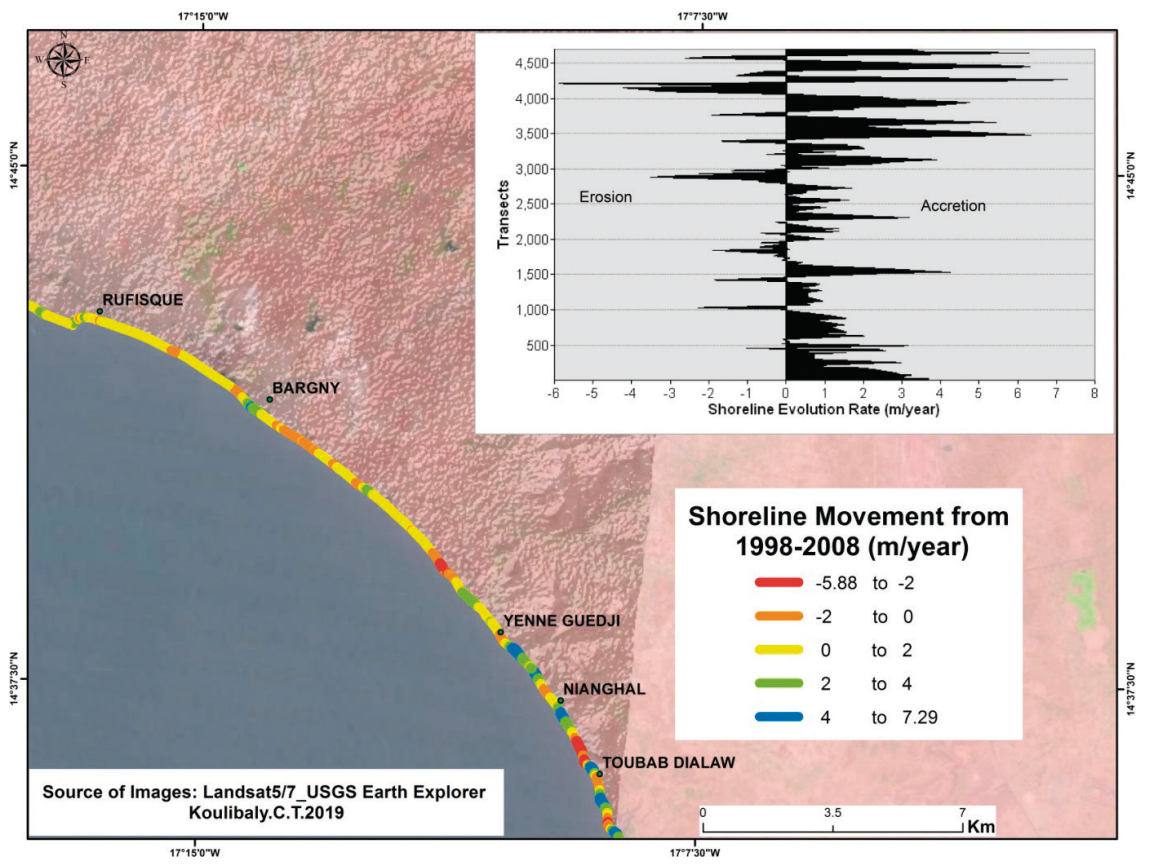

Fig. 9. Shoreline change rate from 1998 to 2008 
The coastline around Rufisque was mainly experiencing accretion of about $1.3 \mathrm{~m} /$ year. In Bargny, the noticed rate of accretion reached $4.15 \mathrm{~m} /$ year while in the localities of Yene Guedj and Nianghal 0.51 and $1.07 \mathrm{~m} /$ year have been recorded respectively. The rare cases of erosion $(-5.88 \mathrm{~m} /$ year $)$ over this period have been recorded towards Toubab Dialaw which also recorded in some of its parts rate of accretion of about $0.5 \mathrm{~m} /$ year.

This trend has been also verified by the analysis of eroded and accreted areas (Fig. 10). It has been recorded for the first time that the accreted surfaces were greater than eroded ones, giving a positive sedimentary balance.

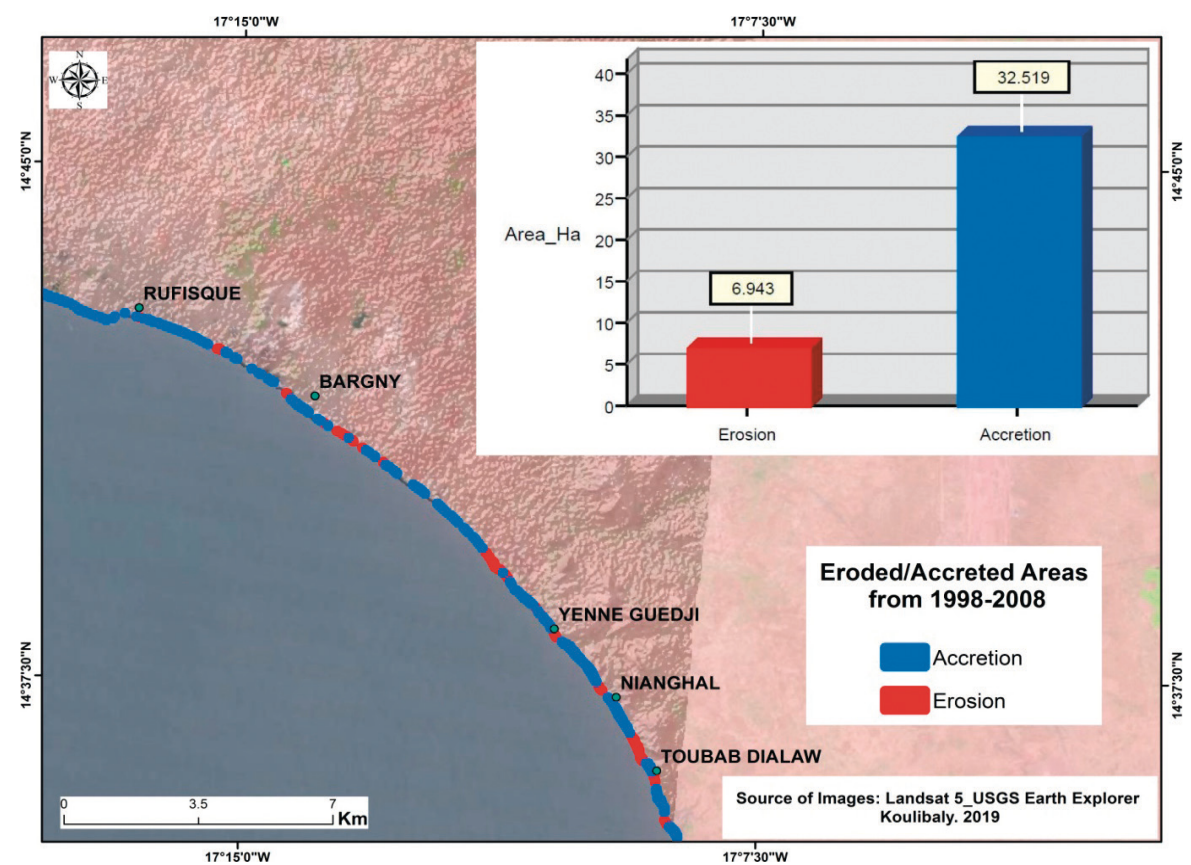

Fig. 10. Eroded/accreted areas [ha] from 1998 to 2008

For this exceptional period 1998-2008, eroded areas were estimated at 6.943 ha while accreted surfaces spans about 32.519 ha, rate of erosion of about 0.694 and $3.251 \mathrm{ha} /$ year of accretion attesting to a positive sedimentary balance with an excess of 25.576 ha.

\section{Shoreline Change Rate from 2008 to 2018 (Figs. 11, 12)}

During this period, the mean coastline change rate was $0.23 \mathrm{~m} /$ year, attesting to important accretion. The maximum rate of erosion was estimated at -6.67 over a minimum of -0.1 while accretion ranges from 0.1 to 7.68 . Figure 11 illustrates shoreline evolution from 2008 to 2018 according to the different rates and locations. 


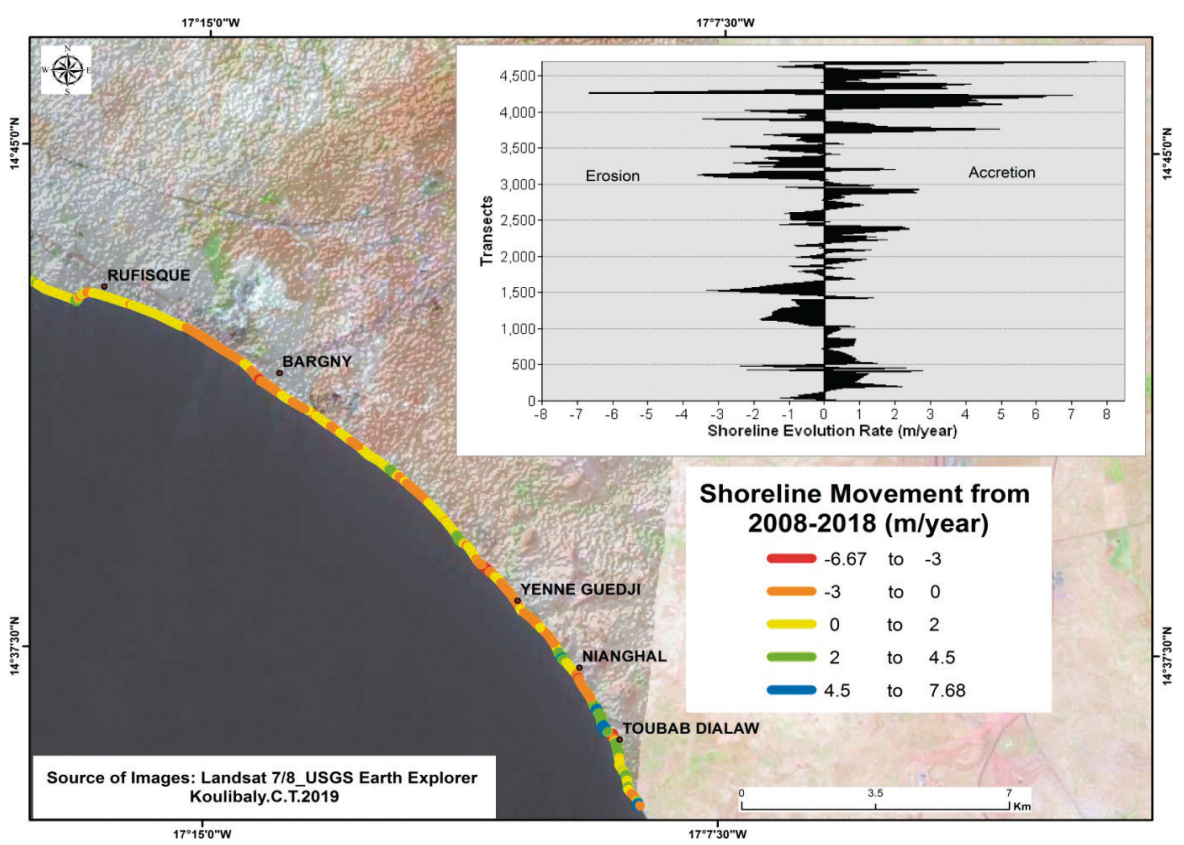

Fig. 11. Shoreline change rate from 2008 to 2018

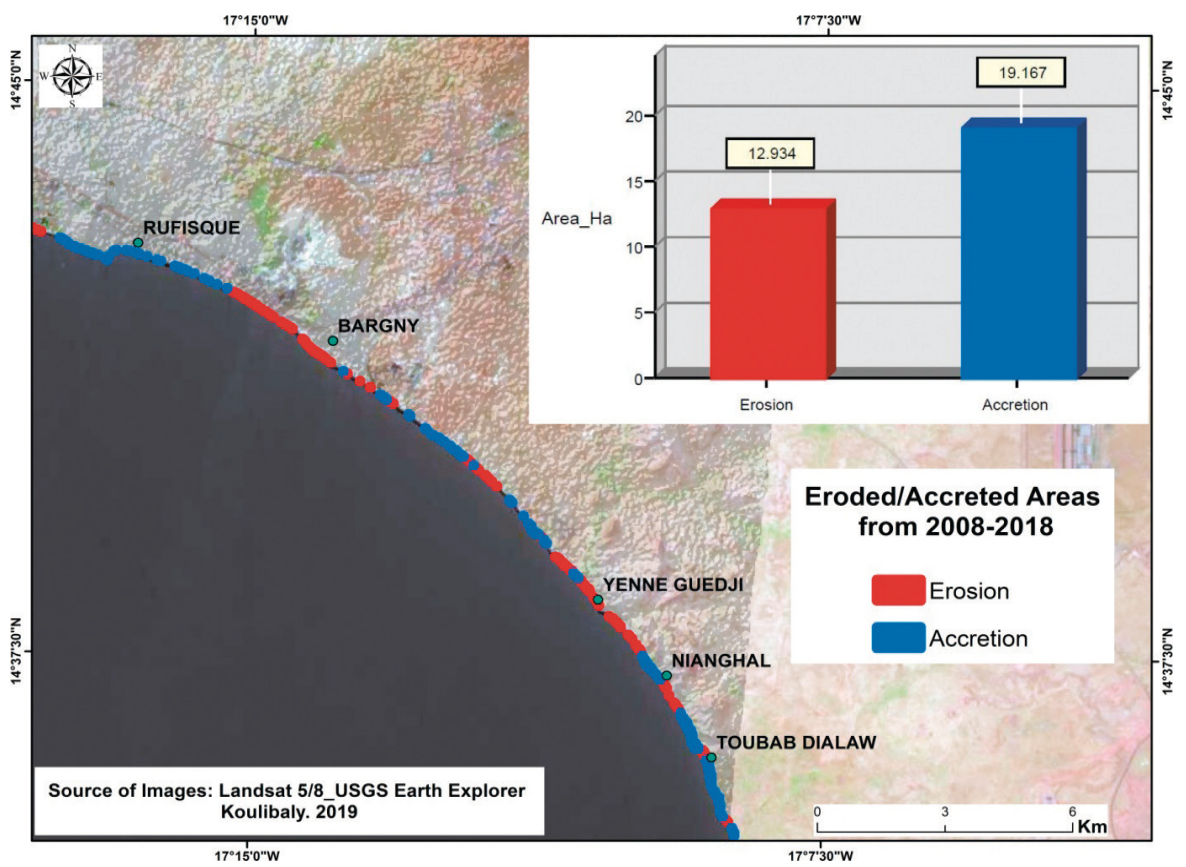

Fig. 12. Eroded/accreted areas [ha] from 2008 to 2018 
It appears that in the locality of Rufisque, the rate of erosion was about $-0.42 \mathrm{~m} /$ year while accretion rate was about $1.43 \mathrm{~m} /$ year. However, the coastal segment encompassing the fishermen villages of Bargny, Yene Guedj is still subject to erosion rates ranging from -2.26 to $-1.64 \mathrm{~m} /$ year while the localities of Nianghal and Toubab Dialaw respectively recorded about 3.58 and $2.59 \mathrm{~m} /$ year of accretion rate.

From 2008 to 2018 the coastline was both subject to erosion and accretion phenomenon with a strong spatial variability. However, it clearly appears that the accretion was more important during that period, with a positive sedimentary balance shown in Figure 12.

From 2008 to 2018, erosion was mainly identified in the villages of Bargny and Yenne Guedj with total eroded areas estimated at $12.934 \mathrm{ha}$, an annual rate of 1.293 ha/year. The city of Rufisque and localities such as Nianghal and Toubab Dialaw have experienced the phenomenon of accretion and the total calculated accreted surfaces were $19.167 \mathrm{ha}$, an annual rate of $1.916 \mathrm{ha} /$ year. The coastline then gained around 6.233 ha, representing a positive sedimentary balance.

\section{Discussion}

The coastline retreat of Rufisque is strongly marked with spatiotemporal changes because it was both subject to different rates of erosion and accretion varying from localities and times series. From 1978 to 2018, the maximum rate of erosion was reached between 1978 and 1988 and estimated about $-19.48 \mathrm{~m} /$ year with a total loss of over 156.81 ha; that period (1978-1988) has been classified as the most intense in terms of erosion because no phenomenon of accretion has been detected throughout the coastline, the mean rate of coastline change was about $-6.95 \mathrm{~m} /$ year. This situation is quite different from the previous study of Niang-Diop [20] that recorded an average rate of $1.20 \mathrm{~m} /$ year decline for the period 1959 to 1980 with maximum retreat observed between 1972 and 1976 with an average rate of $2.8 \mathrm{~m} /$ year. Before then Diallo [18] and Sall [19] had already determined an average decline rate of $1.30 \mathrm{~m}$ per year from 1933 to 1980 . However, both studies mentioned that erosion was very intense and caused serious damage during the 1980s. The phenomenon was less important from 1988 to 1998, when a maximum of $-7.9 \mathrm{~m} /$ year and mean of $-2.58 \mathrm{~m} /$ year of retreat were determined, with a sedimentary deficit of about 77.687 ha. Even if a serious decline in the rate of retreat has been recorded compared to 1978-1988, the majority of the coastline was still experiencing erosion with rare phenomenon of accretion located around the locality of Toubab Dialaw. It is also important to emphasize that towards Rufisque city, some areas remained stable. According to Niang-Diop [20], the reduction in the rate of erosion in the locality of Rufisque was mainly due to the realization of coastal protection facilities between 1983 and 1989. The 1998-2008 period was 
dominated by accretion phenomenon noticed throughout the coastline. The mean rate of shoreline change was for the first time positive and estimated at $1.04 \mathrm{~m} /$ year with a maximum accretion of about $7.29 \mathrm{~m} /$ year and over 32.519 ha of accreted surfaces while erosion ranges from -0.1 to $-5.88 \mathrm{~m}$ /year with a loss of 6.943 ha but a positive sedimentary balance of $25.576 \mathrm{ha}$. Therefore, it clearly appears that the phenomenon of erosion has seriously regressed compared to the previous time series of 1978-1988 and 1988-1998. This regression proved that efforts have been made in terms of coastline management because in 2005, the National Adaptation Plan to climate change was launched with a particular interest in securing the urgent protection of coastal localities such as Rufisque. From 2008 to 2018, the mean coastline change was estimated at $0.23 \mathrm{~m} /$ year attesting to a positive sedimentary balance with the dominance of the phenomenon of accretion mainly felt in the localities of Rufisque and the tourist destination of Toubab Dialaw thanks to coastal protection facilities (dykes, groynes and riprap) while the villages of Bargny and Yene experienced recrudescence of erosion ranging from -2.26 to $-1.64 \mathrm{~m} / \mathrm{year}$. Compared to 1998-2008, it obviously appears that accreted areas have regressed while erosion is taking place.

The results arising from the analysis of coastline changes from 1978 to 2018 are showing two general trends:

- intense erosion process going from 1978 to 1998 with a peak mean of coastline retreat of $-6.95 \mathrm{~m} /$ year,

- accretion process from 1998 to 2018 with a maximum mean of about $1.04 \mathrm{~m} /$ year.
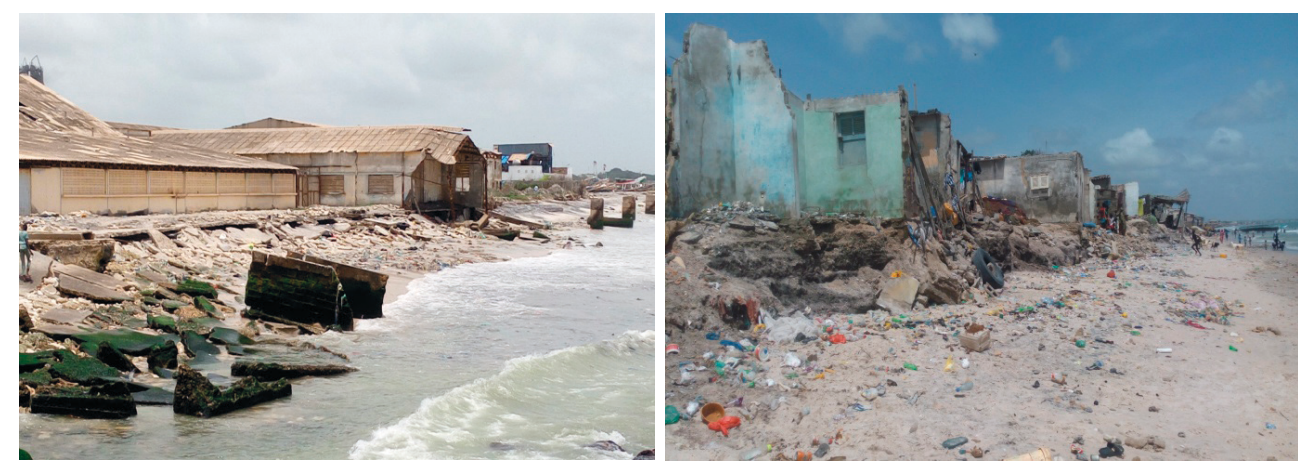

Fig. 13. Ongoing erosion at Rufisque and Bargny Guedj (author's field visit - August 2020)

However, it has been noticed in the field that the phenomenon of erosion is still persisting along the coastline of Rufisque with serious damage inflicted on coastal communities. Figure 13 offers a view of the disastrous effects of coastal erosion across Rufisque' coastline. 
Figure 13 shows that even if important shoreline protection efforts have been felt in Rufisque, the process of coastal erosion is still important on the field as shown by these abandoned buildings collapsing into the sea, while in the fishing village of Bargny Guedj the situation is almost apocalyptic.

Long-term analysis of coastline changes over the Senegalese coastline using DSAS has proven that the south west coast of Senegal (Casamance), where a study carried out from 1968 to 2017, is also subjected to two major trends characterized by a global accretion from 1968 to 1986 followed by a period of beach decline (1986-2017) with an attenuation of erosion process occurring between 2004 and 2017 [36]. Along the North West coast (Saint-Louis), both processes of retreat and accretion were detected from 1978 to 2018 with a rate of coastal erosion ranging from -0.1 to $-35.36 \mathrm{~m} /$ year and accretion from 0.11 to $18.34 \mathrm{~m} /$ year [37]. The same study showed that the coastline of Saint-Louis is also subject to strong spatial variability; some areas located northward such as the fishing villages of Guet-Ndar, Ndar Toute and Goxumbacc were affected with shoreline retreat of $-1.53 \mathrm{~m} /$ year (Guet-Ndar), -2.94 m/year (Ndar Toute) and -1.9 m/year (Goxxumbacc) respectively while the highest rates of erosion (from -9.39 to $35 \mathrm{~m} /$ year) have been recorded around the new mouth [37]. Ultimately, Bakhoum et al. [38] revealed a strong spatial temporal variability of the coastline of Dakar from 1954-2015, with a dominance of eroded surfaces over accreted areas attesting to a negative sedimentary budget. On the same note, Biondo et al. [39] recorded EPR values ranging from -0.51 to $-2.92 \mathrm{~m} /$ year along the Urban Mediterranean beaches such as the gulf of Cagliary from 1954 to 2016.

These long term observations can be compared to the short term assessment of coastline changes showing an alteration of about $21,847.978 \mathrm{~m}$ of the coastline with a rate of $-3.05 \mathrm{~m}$ from 1990 to 2010 in Ghana [40]. It has also been shown that the coastline of Grand Lahou (Ivory coast) was subject to maximum rate of erosion of $2.09 \mathrm{~m} /$ year from 1998 to 2004 [33].

In any case, DSAS has been proven to be a successful tool that definitely contributes to short and long term analysis of coastal erosion emanating from natural and anthropogenic pressure, while the most highlighted ones are more or less related to sea level rise, slope instability, rapid building expansion. The coastline from $\mathrm{Ru}-$ fisque to Toubab Dialaw is experiencing an ongoing urbanization process inducing huge demand for construction materials. Urbanization and economic activities exert considerable pressures on coastal areas, including coastal engineering works, regulation of river basins (in particular the construction of dams), dredging, clearing, extraction of marine aggregates, sand, natural gas and water and land occupancy demands [8]. Armah [40] pointed out that in addition to natural factors, sand mining, infrastructures and other commercial and social activities are among the major drivers of coastal erosion in Ghana. Urbanization also reduces the surface of coastal ecosystems and deeply impacts their natural functioning by contributing to the phenomenon of sediment deficit through sand beach extraction. Diallo [18] mentioned 
out that the estimated daily amount of sand beach mining in Dakar (including Rufisque) ranged from 10 to 15 tons. Figure 14 is actually showing a carter loading sand along the shoreline.

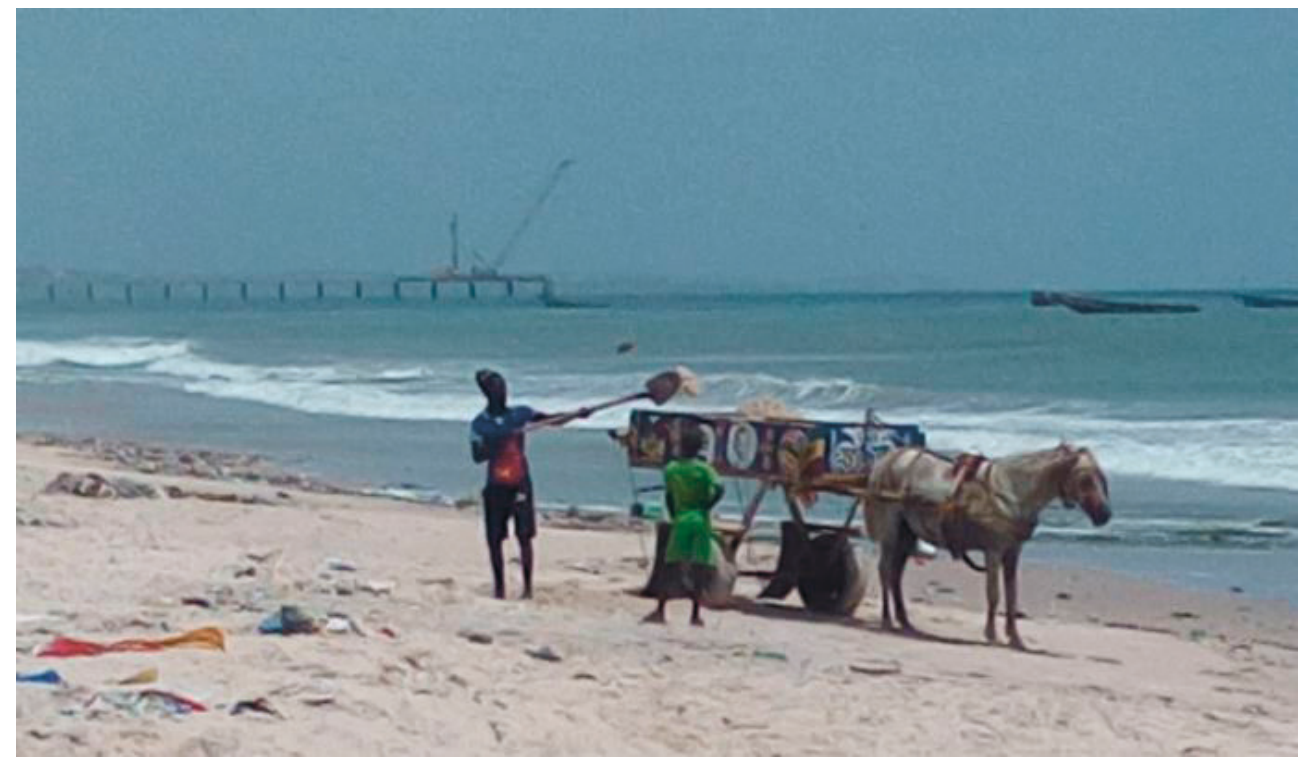

Fig. 14. Ongoing Sand beach extraction at Bargny Guedj (author's field visit - August 2020)

Extraction of beach sand is not a new phenomenon and is very much a current practice. It has long been questioned throughout several countries for its influence on the regressive evolution of coastlines. Despite research in small islands, the Caribbean, Togo [41, 42], in Senegal [18, 19, 20], in Central Africa, Gabon, and the various proposed solutions, it still remains an important driver of coastal erosion. Sand beach mining is a prohibited and punished practice still ongoing along the coastline of Rufisque. Until now, local communities have used the sand for house building and hence worsening their vulnerability to coastal erosion. Therefore, Niazi [43] pointed that the different sections of any coastline are interrelated, acting on a given point (by digging, mining or building) would have inevitable repercussions elsewhere, always negative and very difficult to predict and then intensifying coastline vulnerability.

The erection of infrastructure (dams, dikes) on watercourses may reduce the solid transport by trapping millions of cubic meters of sediment per year. These sediments therefore no longer reach the mouths of rivers and neighboring coasts, which creates a significant sediment deficit as rivers are significant coastal sediment suppliers [44]. 
On the other hand, coastal facilities (riprap, breakwaters, jetties, etc.), intended to properly protect by fixing the coastline, strongly modify the methods of transporting coastal sediments and can accelerate erosion phenomena by laterally deferring it [45]. It has also been highlighted that the destruction of vegetation through anthropogenic action as a non-neglected driver of coastline retreat as vegetal cover plays a positive role in increases the resistance to erosion [8].

Erosion is also exacerbated by the narrowness of the continental shelf which facilitates the entry of waves with strong energy. Wide beaches have a better ability to cushion crises than narrow beaches [46-48]. However, the plateau of the Cape Verde peninsula is extremely narrow $(2-5 \mathrm{~km})$ with continental slope of $1-1.5 \%$, facilitating movements of sediment in deep water towards the open sea [20] and exposure to sudden and unpredictable storm surges [43].

\section{Adaptation Strategies}

Along Rufisque' coastline, local communities are attempting to protect their amenities against the sea using different methods. Figure 15 shows the different community based adaptation strategies, mainly including the use of sandbags, tires, and cement blocks.
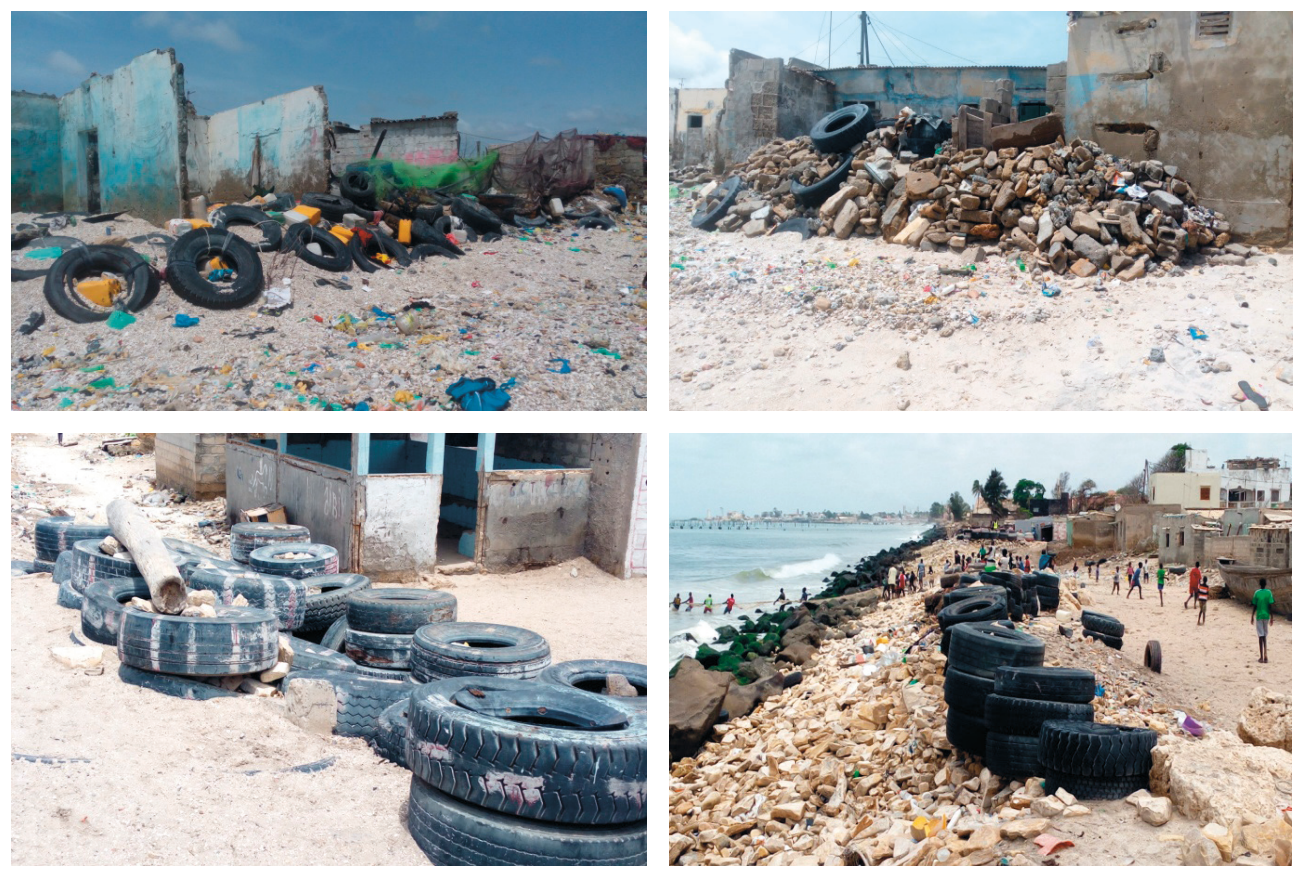

Fig. 15. Community based adaptation strategies to coastal erosion in Rufisque and Bargny (author's field visit - August 2020) 
It has been noticed that bags are filled with beach sand and superposed along houses while two forms of uses have been observed for the tires. In some areas tires are horizontally superposed and filled with sand, rocks or cement blocks, in others they are firstly tied together and half buried along houses. These desperate attempts to protect their amenities are still inadequate to face the disastrous effects of coastal erosion.

However, some efforts of coastline protection have been put in place by local authorities. Projects of huge structural coastal protection facilities such as dykes, groynes, riprap and walls have been implemented. The latest infrastructure against coastal erosion is the frontal dyke of Thiawlene inaugurated in July 2013. Figure 16 offers a frontal view of that infrastructure.

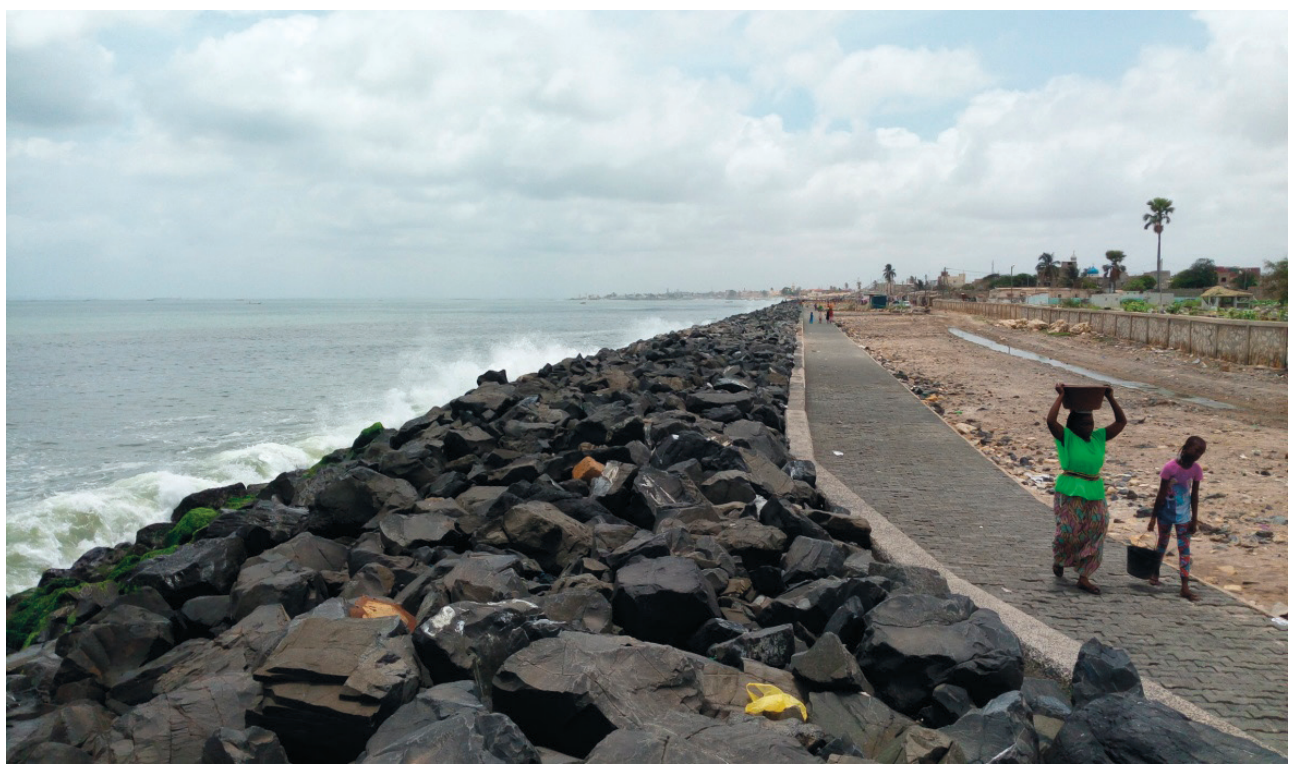

Fig. 16. The Frontal Dyke of Thiawlene (Rufisque) (author's field visit - August 2020)

This dyke is $730 \mathrm{~m}$ in length and $23 \mathrm{~m}$ in width, and was executed at the cost of 6.5 million USD from the West Africa Monetary Union. The idea of building a new dyke, especially in the Rufisque-Est area, started from the tragedy of July 2007 when serious damages were recorded by the communities there, including the collapse of the fence wall of the local cemetery.

\section{Conclusion}

The study analyzed the phenomenon of coastline changes along Rufisque from 1978 to 2018 at 10 year intervals. It concluded that the evolution of the shoreline was marked by strong spatial and temporal variations. Both the phenomenon 
of erosion and accretion were identified along the study area with different rates. According to our time series, erosion was more active from 1978 to 1998 while consequent accretion took place from 1998 to 2018. Coastline retreat was mostly felt in the localities of Bargny, Yene Guedj and Nianghal while Rufisque and Toubab Dialaw recently recorded important levels of accretion. However, the study found that the process of erosion is still very active along the coastline with serious effects on coastal communities. It was also noticed that the community based adaptation strategies to coastline erosion are still crude and temporary and unadapted to face such disasters as storm surges. Finally, appropriated coastal protection facilities involving huge structural facilities such as dykes and groynes have only been identified at Rufisque, being the sole area to benefit from these kinds of infrastructure, while in areas such as Bargny, mainly inhabited by modest fishing communities, the situation is still alarming and at times desperate. Therefore, more efforts should be concentrated in terms of coastal protection facilities along these localities. Our study also opines that the community dimension must be included in both local and national plan regarding adaptation to sea level rise and its resulting impacts such as coastal erosion.

\section{References}

[1] Cazenave A., Llovel W.: Contemporary Sea Level Rise. Annual Review of Marine Science, vol. 2, 2010, pp. 145-73. https://doi.org/10.1146/annurev-marine-120308-081105.

[2] Burkett V.R., Davidson M.A. (eds.): Coastal Impacts, Adaptation and Vulnerability: A Technical Input to the 2012 National Climate Assessment. Cooperative Report to the 2013 National Climate Assessment, 2012. https://www.researchgate.net/profile/S_Jeffress_Williams/publication/299976417_Physical_ Climate_Forces/links/5af599a3a6fdcc0c030bbe0d/Physical-Climate-Forces. pdf [access: 11.08.2015].

[3] World Bank: Climate Risk and Adaptation Country Profile: Senegal. 2011. https://climateknowledgeportal.worldbank.org/sites/default/files/2018-10/ wb_gfdrr_climate_change_country_profile_for_SEN.pdf [access: 4.07.2019].

[4] World Bank: Economic and spatial Study of the Vulnerability and Adaptation to Climate Change of Coastal areas in Senegal. 2013. http://documents1.worldbank. org/curated/en/537811468305337766/pdf/837830WP0P12030Box0382112B00PUBLIC0.pdf [access: 5.08.2015].

[5] Direction de 1'Environnement et des Etablissements Classés du Sénégal and Centre de suivie écologique: Rapport sur l'Etat de l'environnement au Sénégal. Ministère de l'Environnement et de la Protection de la Nature, 2005.

[6] Niang I., Dansokho M., Faye S., Gueye K., Ndiaye P.: Impacts of climate change on the Senegalese coastal zones: Examples of the Cap Vert peninsula and Saloum estuary. Global and Planetary Change, vol. 72, issue 4, 2010, pp. 294-301. https://doi.org/10.1016/j.gloplacha.2010.01.005. 
[7] Drammeh F.: Assessing and adapting to climate-change induced sea level rise on the Southern coastline of the Gambia. 2013. https://www.un.org/ Depts/los/nippon/unnff_programme_home/fellows_pages/fellows_papers/ Drammeh_1314_Gam.pdf [access: 14.06.2015].

[8] European Commission: Living with coastal erosion in Europe: sediment and space for sustainability. Part II Maps and statistics. Report Directorate General of Environment, European Commission, Brussels 2004.

[9] Morton R.A., Miller T., Moore L.J.: Historical shoreline changes along the US Gulf of Mexico: A summary of recent shoreline comparisons and analyses. Journal of Coastal Research, vol. 21, no. 4, 2004, pp. 704-709. https://doi.org/10.2112/040230.1.

[10] Morton R.A., Miller T.L.: National assessment of shoreline change: Part 2. Historical shoreline changes and associated coastal land loss along the U.S. Southeast Atlantic Coast. U.S. Geological Survey Open File Report, 2005-1401.

[11] Hapke C.J., Reid D., Richmond B.M., Ruggiero P., List J.: National Assessment of Shoreline Change. Part 3: Historical Shoreline Change and Associated Coastal Land Loss Along Sandy Shorelines of the California Coast. USGS Report, U.S. Department of the Interior, U.S. Geological Survey, 2016. https://pubs.usgs. gov/of/2006/1219/of2006-1219.pdf [access: 22.09.2020].

[12] Dillenburg S.R., Esteves L.S., Tomazelli L.J.: A critical evaluation of coastal erosion in Rio Grande do Sul, Southern Brazil. Annals of the Brazilian Academy of Science, vol. 76, no. 3, 2004, pp. 611-623. https://doi.org/10.1590/S000137652004000300014.

[13] Gopinath G., Seralathan P.: Rapid Erosion of the coast of Sagar island, West Bengal - India. Environmental Geology, vol. 48(8), pp. 1058-1067. https://doi. org/10.1007/s00254-005-0044-9.

[14] El-Hattab M.: Improving Coastal Vulnerability Index of the Nile Delta Coastal Zone, Egypt. Journal of Earth Science \& Climatic Change vol. 6, issue 8, 2015, art. no. 293. https://doi.org/10.4172/2157-7617.1000293.

[15] Torresan S., Furlan E., Critto A., Michetti M., Marcomini A.: Egypt's Coastal Vulnerability to Sea-Level Rise and Storm Surge: Present and Future Conditions. Integrated Environmental Assessment and Management, vol. 16, issue 5, 2020, pp. 761-772. https://doi.org/10.1002/ieam.4280.

[16] Makota V., Sallema R., Mahika C.: Monitoring shoreline change using remote sensing and GIS: A case study of Kunduchi area, Tanzania. Western Indian Ocean Journal Marine Science, vol. 3, no. 1, 2004, pp. 1-10.

[17] Ozer P., Hountondji Y.-C., De Longueville F.: Evolution récente du trait de côte dans le golfe du Bénin. Exemples du Togo et du Bénin. Geo-Eco-Trop: Revue Internationale de Géologie, de Géographie et d'Écologie Tropicales, vol. 41, issue 3, 2017, pp. 529-541.

[18] Diallo S.: Evolution géomorphologique du littoral sur la Petite Côte à Rufisque. Mémoire de Maîtrise, Université de Dakar, Dakar 1982. 
[19] Sall M.: Dynamique et morphogénèse actuelles au Sénégal Occidental. Université Louis Pasteur, Strasbourg 1982 [Ph.D. thesis].

[20] Niang-Diop I.: L'érosion côtière sur la petite côte du Sénégal à partir de l'ensemble de Rufisque: passé, présent et futur. Thèses et Documents Microfichés, 159, ORSTOM, Paris 1996. https://horizon.documentation.ird.fr/exl-doc/pleins_ textes/pleins_textes_6/TDM/010008221.pdf [access: 17.07.2015].

[21] Dieye A.: Traitement informatique de photographies aériennes combiné à l'utilisation de systèmes d'information géographique pour l'étude de la ligne de rivage entre Rufisque et Bel Air durant la période 1968-1997. Mémoire de D.E.A en Géosciences: Environnements sédimentaires, Université Cheikh Anta DIOP de Dakar, Dakar 2000.

[22] Guerin K.: Dynamique du littoral sableux de Tiaroye à Bargny (Baie de Gorée - Sénégal). Mémoire de Maîtrise de Géographie, Université de Paris, Sorbonne, Paris 2003.

[23] AgenceNationaledelaStatistiqueetdelaDemographie:Recensement Généralde Population et de l'Habitat, de l'Agriculture et de l'Elevage. 2013. https://www.ansd. sn/ressources/RGPHAE2013/ressources/doc/pdf/RGPHAE-Rapport-regional_DAKAR_vf.pdf [access: 10.12.2020].

[24] Dubresson A.: L'espace Dakar-Rufisque en devenir: de l'héritage urbain à la croissance industrielle. ORSTOM, Paris 1979. https://horizon.documentation.ird. fr/exl-doc/pleins_textes/pleins_textes_5/pt5/travaux_d/00855.pdf [access: 12.06.2020].

[25] Diallo M.: Etude du centre-ville de Rufisque, mutations fonctionnelles et Caractéristiques du paysage urbain. 2009. https://www.institut-numerique.org/etudedu-centre-ville-de-rufisque-caracteristiques-du-paysage-urbain-et-mutations-fonctionnelles-4ffaa47f679cc/amp. [access: 12.06.2020].

[26] Roche A., Bosc Ch., Chandelier L., Lagnous R.: Apport de l'imagerie satellitaire pour le suivi du trait de côte. [in:] XIII èmes Journées Nationales Génie Côtier - Génie Civil, Dunkerque, 2-4 juillet 2014, Editions Paralia CFL, 2014, pp. 621-628. https://doi.org/10.5150/jngcgc.2014.068.

[27] Wicaksono A., Wicaksono P., Khakhim N., Farda N., Marfai M.A.: Semi-automatic shoreline extraction using water index transformation on Landsat 8 OLI imagery in Jepara Regency. [in:] Sixth International Symposium on LAPAN-IPB Satellite, vol. 11372, SPIE, 2019, pp. 500-509. https://doi.org/10.1117/12.2540967.

[28] Goneri L.C., Cazenave A., Garcin M., Becker M., Donato V. et al.: L'elevation recente du niveau marin et l'erosion cotiere: le cas d'iles oceaniques du Pacique. Géosciences, 2011, pp. 92-99. https://hal-brgm.archives-ouvertes.fr/hal00656782/document [access: 8.08.2020].

[29] Grenier A., Dubois J.-M.M.: Évolution des côtes aux Îles-de-la-Madeleine. [in:] Dubois J.-M.M., Gagnon J. (eds.), Les Îles-de-Ia-Madeleine: un pays à découvrir, Info GéoGraphes, no. 1 (numéro spécial), 1992, pp. 59-64. 
[30] Mishra M., Sudarsan D., Kar D., Naik A., Das P., Santos C., da Silva R.: The development and research trend of using dsas tool for shoreline change analysis: A scientometric analysis. Journal of Urban and Environmental Engineering, vol. 14, 2020, pp. 69-77. https://doi.org/10.4090/juee.2020.v14n1.069077.

[31] Dewidar K.M., Frihy O.E.: Pre- and post-beach response to engineering hard structures using Landsat time-series at the northwestern part of the Nile delta, Egypt. Journal of Coastal Conservation, vol. 11, 2008, pp. 133-142. https://doi. org/10.1007/s11852-008-0013-z.

[32] Moisan M., De La Torre Y.: Evolution du trait de côte en Guyane: Caraterisation dynamique cotiere entre 1950 et 2013 à l'echelle regionale. Rapport final BRGM/RP-62904-FR, 2014.

[33] Valère D.E.M., Fatoumata B., Jeanne K.M., Jean-Baptiste K.A., Brice Hervé M.A., Kouamé A.K., André T.J., Patricia Y.: Cartographie De La Dynamique Du Trait De Côte A Grand-Lahou: Utilisation De L'outil « Digital Shoreline Analysis System (Dsas)». European Scientific Journal, vol. 12, 2016, pp. 327-335. https://doi.org/10.19044/esj.2016.v12n36p327.

[34] Kuleli T., Bayazıt Ş.: Coastline change detection by using Digital Shoreline Analysis System (DSAS) and Remote Sensing. [in:] $3^{\text {rd }}$ International Conference on Engineering Technology and Applied Sciences. Vol. 1, Üsküp, Macedonia, 2018, pp. $488-494$.

[35] Thinh N., Hens L.: A Digital Shoreline Analysis System (DSAS) applied on mangrove shoreline changes along the Giao Thuy Coastal area (Nam Dinh, Vietnam) during 2005-2014. Vietnam Journal of Earth Sciences, vol. 39, 2017, pp. 87-96. https://doi.org/10.15625/0866-7187/39/1/9231.

[36] Thior M., Sane T., Sy O., Descroix L., Ba B.D., Solly B., Mendy V.: Analyse Spatiale de l'évolution du Trait de Côte Autour de l'embouchure du Fleuve Casamance (Sénégal) de 1968 à 2017, à Partir de l'outil DSAS. European Scientific Journal, vol. 15, no. 9, 2019, pp. 106-130. https://doi.org/10.19044/esj.2019. v15n9p106.

[37] Koulibaly C.T., Ayoade J.O.: Coastal Vulnerability Assessment of Saint-Louis/Senegal to Sea Level Rise. Global Scientific Journals, vol. 9, issue 1, 2021, pp. 213-238.

[38] Bakhoum P., Diaw A., Sambou B.: A peninsula in coastal erosion? Dakar, the Senegalese capital city facing the sea level rise in the context of climate change. Environmental and Water Sciences, Public Health and Territorial Intelligence Journal, vol. 2, no. 1, 2018, pp. 91-108. https://doi.org/10.48421/IMIST. PRSM/ewash-ti-v2i1.11303.

[39] Biondo M., Buosi C., Trogu D., Mansfield H., Vacchi M., Ibba A., Porta M., Ruju A., De Muro S.: Natural vs. Anthropic Influence on the Multidecadal Shoreline Changes of Mediterranean Urban Beaches: Lessons from the Gulf of Cagliari (Sardinia). Water, vol. 12, 2020, art. no. 3578. https://doi.org/10.3390/w12123578. 
[40] Armah F.: GIS-based Assessment of Short Term Shoreline Changes in the Coastal Erosion-Sensitive Zone of Accra, Ghana. Research Journal of Environmental Sciences, vol. 5, issue 7, 2011, pp. 643-654. https://doi.org/10.3923/rjes.2011.643.654.

[41] Blivi A.: Vulnérabilité de la côte togolaise à l'élévation du niveau marin: une analyse de prévision et d'impact, in Le tricentenaire d'Aného et du pays Guin. [in:] Le tricentenaire d'Aného et du pays guin: Société, culture et développement en pays guin, Patrimoines, no. 11, Presse de l’U.B, 2001, pp. 643-660.

[42] Kwassi A.L.: Contribution à l'étude des populations rurales de la zone côtière du Togo. Mémoire de maîtrise, Université du Bénin, Lomé 2002.

[43] Niazi S.: Evaluation des impacts des changements climatiques et de l'élévation du niveau de la mer sur le littoral de Tétouan (Méditerranée occidentale du Maroc): Vulnérabilité et Adaptation. Université Mohammed-V de Rabat, Rabat 2007 [Ph.D. thesis].

[44] Ley de la Vega C., Favennec J., Gallego-Fernandez J., Pascual Vidal C.: Conservation des dunes côtières: restauration et gestion durables en Méditerranée occidentale. UICN, Gland, Suisse et Malaga, Espagne, 2012.

[45] Ministère de l'Écologie, du Développement durable et de l'Énergie: Développer la connaissance et l'observation du trait de côte. Contribution nationale pour une gestion intégrée. Paris 2016.

[46] Paskoff R.: Côtes en danger. Coll. «Pratiques de la Géographie», Masson, Paris 1993.

[47] Cazes-Duvat V.: A beach vulnerability index and its implementation in the islands of Seychelles. Géomorphologie: relief, processus, environnement, no. 1, 2001, pp. 31-40. https://doi.org/10.3406/morfo.2001.1084.

[48] Suanez S., Fichaut B., Magne R, Ardhuin F., Corman D., Stephan P., Cariolet J.M.: Changements morphologiques et budget sédimentaire des formes fuyantes en queue de comète de l'archipel de Molène (Bretagne, France). Géomorphologie: relief, processus, environnement, no. 2, 2011, pp. 187-204. https://doi. org/10.4000/geomorphologie.9397. 